\title{
COVID-19 PANDEMIC AND OUTWARD FOREIGN DIRECT INVESTMENT: A PRELIMINARY NOTE
}

\author{
Folorunsho M. Ajide $^{1} \&$ Tolulope T. Osinubi ${ }^{2}$
}

date of paper receipt: 02.10.2020.

Original Article date of sending to review: 05.10.2020.

doi: 10.2478/eoik-2020-0019 date of review receipt:

15.10.2020.

UDK 578.834:616.98:[316.62

${ }^{1}$ University of Ilorin, Ilorin, Nigeria

${ }^{2}$ Obafemi Awolowo University, Ile-Ife, Nigeria

\begin{abstract}
Social-distance policy of most governments and the pandemic impact of corona virus (COVID-19) on human health are expected to shutter international investment and business environment. However, there is little or no study to show the early empirical evidence on this relationship, most especially its impacts on FDI flows in the economies. This note provides a preliminary evidence of the impact of COVID-19 on FDI outflows. Our data cover cross-sectional first quarter, average data; between 1 January - 31 March, 2020 from 43 countries. Using Ordinary least square (OLS) and Quantile regressions, we document that there is a positive relationship between COVID-19 confirmed cases and FDI outflows. In addition, there is a positive impact of COVID-19 related confirmed deaths on FDI outflows across all quartiles estimations. This means that COVID-19 pandemic fuels the foreign direct investment outflows. The major causes could be the reduction in the ability of firms to invest due to a shortage in the number of skilled employees because they care for their health safety, a decline in corporate profits and increase in cost of finance. In addition, the propensities to invest have been widely affected negatively in most economies. These factors also become obvious when most economies experience a very high level of risk perception in financial market.
\end{abstract}

Keywords:

COVID-19, Cross-sectional Analysis, FDI, Quantile Regressions. 


\section{INTRODUCTION}

This note sets to provide a preliminary evidence of the impact of Corona virus disease (henceforth COVID-19) on foreign direct investment outflows in the economy. This study is motivated to aid policy makers on early policy draft towards economic recovery aftermath COVID-19 pandemic. This becomes paramount given the need to analyze the potential negative impacts of the pandemic on the global economy. Prior to the outbreak of COVID-19, the global environment for foreign direct investment (FDI) has already been characterized by a lower level of investors' confidence due to uncertainty in trade and investment policies, weakening global growth, dwindling commodity prices and increasing protectionism (Saurav et al., 2020).

COVID-19 originated from Wuhan in China in December 2019 before spreading to other countries in 2020. On March 11th 2020, the World Health Organisation (WHO) declared COVID -19 a pandemic due to its global widespread. This implies that presently, COVID-19 is a global crisis affecting the global economy (Fairlie, 2020). The pandemic is considered to be one of the deadliest diseases in human history and this caused almost all the countries to go on total/partial lockdown. Recently, most countries are easing the lockdown measures as the number of cases and deaths reduces. Since the outbreak of the disease till August 28th, 2020, WHO reported over 24 million cases of COVID-19 and more than 820 thousand deaths. Specifically, the American region is the most vulnerable with more than 12 million cases and over 450 thousand deaths. The least vulnerable region is the Western Pacific region with over 400 thousand cases and more than 10 thousand deaths (see Figure 1).

Figure 1. World distribution of COVID-19 cases and deaths according to WHO regions

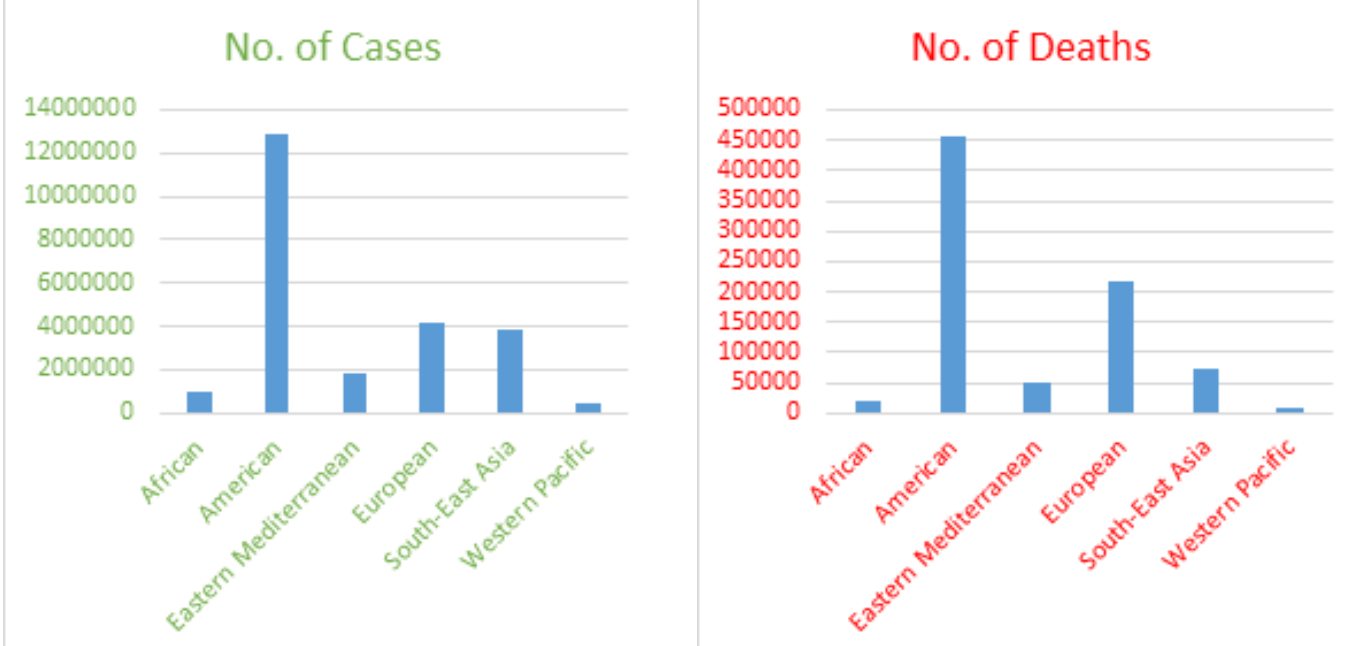

Source: Authors' Compilation (WHO, 2020)

Consequently, economic globalisation is one of the most affected variables during this pandemic and FDI as one of its measures has witnessed an ebb due to the pandemic (Seric \& Hauge, 2020). The United Nations Conference on Trade and Development (UNCTAD, 2020) reported that lockdown measures have a negative effect on investment prospects and have caused multinational enterprises to reassess new projects. To confirm this, International Monetary Fund (IMF) in late March reported that investors withdrew over US $\$ 100$ billion of portfolio investment from developing countries since the outbreak of COVID-19. This represents the largest capital outflow ever recorded. This supports the UNCTAD's projection that global FDI flows would reduce by $40 \%$ between 2020 and 2021.

Even though the developing countries are the least vulnerable, the countries experienced a greater decline in FDI inflows when compared to the developed countries. FDI in the developing countries 
would contract more than the projected global average because (i) the sectors that attract FDI into the countries have been deeply hit by the pandemic, and (ii) the developing countries in recent times are largely dependent on FDI making the countries' FDI inflows rose from US $\$ 14$ billion in 1985 to US $\$ 706$ billion (current prices) in 2018. This indicates a 29\% increase (check Seric \& Hauge, 2020). Likewise, UNCTAD (2020) predicted that investment inflows would reduce by 2545\%, 45\% and half in Africa, Asia and Latin America respectively in 2020.

Meanwhile, the world's FDI may recover from COVID-19 pandemic as a result of "global value chains," "replenishment of capital stock," "recovery of the global economy" and "restructuring for resilience (UNCTAD, 2020; Jelilov et al. 2020). According to Mukhisa Kituyi, the UNCTAD Secretary-General, the recovery is greatly uncertain and subject to both the duration of the COVID-19 (health crisis) and the efficacy of the policies that lessen the economic effects of the pandemic. From the foregoing, it becomes important to provide early evidence to aid policy makers by examine the impact of COVID-19 on FDI outflows in the economy. The explanation for this is based on the fact that FDI is predicted to reduce during the duration of the pandemic, but there is little or no empirical evidence to support this. Hence, this study.

\section{LITERATURE REVIEW}

There is a paucity of study on the relationship between COVID-19 and FDI. Meanwhile, several studies have documented that any form of crisis; be it economic or financial, is detrimental to the flows of FDI. In investigating the relationship between financial crisis and FDI, Dornean, et al. (2012) examined how global financial crisis influences FDI in the Central and Eastern European (CEE) countries using a regression and panel data methodology. Their results show that financial crisis reduces the level of FDI in the selected countries as expected (see also Alfaro and Chen, 2010). Relatedly, using semi-parametric generalized partial linear models in developing countries, Ucal et al. (2010) investigated the nexus between financial crisis and FDI. Their findings reveal that the crisis negatively affects the inflow of FDI in the countries studied as the FDI inflows increase in the year preceding and decline in the years after the financial crisis. Using a panel data from 23 developed countries, Liu (2012) analysed the effects of financial crises (currency crisis, banking crisis and inflation crisis) on FDI. The author reported that the financial crises in the countries sampled are adversely linked to FDI. In reference to Asian Financial crisis, most studies have argued that the crisis has negatively influenced the inflow of FDI. For example, Kian Wie (2006) studied investment climate and FDI found that both FDI and domestic investment reduce drastically due to the deteriorating investment climate.

On economic crisis, Dornean and Oanea (2015) found a similar result that economic crisis has an adverse effect on FDI in CEE countries except in some few cases where FDI increases in the face of economic crisis. Poulsen and Hufbauer (2011) compared the current FDI recession with FDI responses to past economic crises with the findings that the past crises greatly influenced FDI in developed countries, while the level of FDI remains stable in the emerging economies.

Asides economic and financial crisis, health crisis also has a way of affecting FDI. Given that governments of all countries need to take appropriate steps to control the spread of COVID-19, the impact on FDI is strongly felt. The World Investment Report 2020 by UNCTAD confirmed that FDI responds negatively to COVID-19 especially in the developing countries (Seric \& Hauge, 2020). In the same vein, the World Bank Group's pulse survey in March 200 showed that the pandemic would negatively affect FDI in developing countries (Aslam, 2015; Saurav, Kusek \& Kuo, 2020). According to Zhan (2020), economic impact estimates and earnings revisions of the 5,000 largest multinational enterprises (MNEs) as reviewed by UNCTAD, indicate that FDI could reduce by $30 \%$ to $40 \%$ in 2020 and 2021. In addition, the InvestChile study (2020) documented that capital spending, investment in new areas and expansions are all hindered by the physical closure of some areas and the slowdown in production. The implication is that almost all countries in the world will experience a decrease in FDI inflows. In line with the above, Organisation for Economic Co- 
operation and Development (2020) projected that FDI flows will decline by more than $30 \%$ in 2020 . This is as result of the policy steps taken by governments to control the spread of the COVID-19 pandemic and the subsequent recession (see also World Association of Investment Promotion Agencies, 2020). Furthermore, empirical studies have shown that COVID-19 has a negative effect on FDI. For instance, employing a panel data on CEE (Central and Eastern European) economies, Radu et al. (2020) showed that FDI flows are decreasing due to COVID-19 crisis and this may lead to a contraction in CEE economies.

Summarily, all crises (economic, financial and health) have an adverse impact on FDI flows, especially in the developing countries. This study sets to empirically examine the impact of health crisis (COVID-19), as opposed economic and financial crisis, on FDI outflows in OECD and nonOECD countries.

\section{DATA AND METHODOLOGY}

In this study, Ordinary Least Square and Quantile Regression estimation techniques are applied to analyse the data mainly due to its nature as explained below.

\subsection{ORDINARY LEAST SQUARE}

Since the study relies on cross-sectional averaged data, Ordinary least square (OLS) is used for the study to follow the extant literature (Andrés, 2006; Kodila-Tedika \& Asongu, 2015; Asongu et al., 2019). Following the study of Stoddard and Noy (2015), Dornean and Oanea (2015), equation (1) expresses the relationship between FDI outflows and COVID-19 variables including control variables.

$$
\operatorname{LFDIO}_{i}=\partial_{1}+\partial_{2} \operatorname{COVIDCAses}_{i}+\partial_{3} X_{i}+u_{i}
$$

Where LFDIO_i is the natural log of foreign direct investment outflows; COVID Cases_i is log of Covid-19 confirmed cases (LCOC) or Log of COVID-19 Confirmed Death (LCOD). i is an indicator for each country while $\partial \_1$ stands for constant, $\mathrm{X}$ is a vector of control variables, and $\mathrm{u} \_\mathrm{i}$ stands for error term. X contains the following variables: Log of Business Confidence Index (LBCI), Consumer Price Index (CPI), and Short-term Interest rate (INT).

\subsection{QUANTILE REGRESSIONS}

For robustness check, we employ Quantile regression (QR) in order to mitigate the static assumption of conditional mean of the dependent variable under OLS technique. The QR enables us to estimate the parameter throughout the conditional distribution of the dependent variable (Koenker \& Bassett, 1978; Asongu et al, 2019). Using this technique, we are able to estimate the lower, intermediate and higher level of FDI outflow. The conditional quantile of the FDI outflows, LFDIO_i, given $X \_i$ is shown as:

$Q_{L F D I}\left(\theta / X_{i}\right)=X_{i}^{\prime} \partial_{\theta}$

Where $\theta(0,1)$ and unique slope parameters are modelled for each $\theta \wedge$ th specific quantile. The equation (2) is comparably to be the same with the slope in OLS but parameters are assessed at the conditional mean of LFDIO. X_i is the vector of explanatory variables. QR minimizes the weighted summation of absolute deviations for different quantiles (Asongu et al. 2019). 


\subsection{DATA SOURCES AND VARIABLES DESCRIPTIONS}

In this study, our choice of selection of countries are based on data availability. As a result, we have 43 countries in total. These countries are Australia, Austria, Belgium, Braze, Canada, Chile, China, Colombia, Czech, Denmark, Estonia, Finland, France, Germany, Greece, Hungary, India, Indonesia, Iceland, Ireland, Israel, Italy, Japan, Korea, Latvia, Lithuania, Luxemberg, Mexico, Netherlands, New Zealand, Norway, Poland, Portugal, Russia, Slovakia, Slovenia, South Africa, Spain, Sweden, Switzerland, Turkey, UK, and USA. Our data cover cross-sectional first quarter, average data; between 1 January - 31 March, 2020 from 43 countries. This period covered the early stage in which most countries are hit by COVID-19. Our source of data include OECD database [for FDI outflows, short-term interest rate, Consumer Price Index, Business Confidence Index] and World Health Organisations [for COVID-19 Confirmed Cases and COVID-19 Confirmed Death].

Table 1. Descriptive statistics

\begin{tabular}{|c|c|c|c|c|c|c|}
\hline & LFDIO & LCOD & LCOC & INT & CPI & LBCI \\
\hline Mean & 7.650163 & 6.712374 & 9.755029 & 3.609612 & 5.859510 & 5.962368 \\
\hline Median & 7.842941 & 6.436150 & 9.639782 & -1.470500 & 5.084015 & 5.979865 \\
\hline Maximum & 10.84643 & 10.96353 & 13.81948 & 28.15000 & 17.00000 & 6.001261 \\
\hline Minimum & 2.869320 & 2.708050 & 6.744059 & -2.663800 & 1.438190 & 5.680021 \\
\hline Std. Dev. & 1.981743 & 2.149967 & 1.680553 & 8.504002 & 4.943093 & 0.073305 \\
\hline
\end{tabular}

Note: $\log$ of Covid-19 confirmed cases (LCOC), Log of COVID-19 Confirmed Death (LCOD), Log of Business Confidence Index (LBCI), Consumer Price Index (CPI), and Short-term Interest rate (INT).

Source: Authors' computation

Table 2. Pairwise Correlation

\begin{tabular}{|c|c|c|c|c|c|c|}
\hline & LFDIO & LCOD & LCOC & INT & CPI & LBCI \\
\hline LFDIO & 1.000000 & & & & & \\
\hline LCOD & 0.716640 & 1.000000 & & & & \\
\hline LCOC & 0.735902 & 0.950041 & 1.000000 & & & \\
\hline INT & -0.069091 & -0.065523 & -0.010430 & 1.000000 & & \\
\hline CPI & -0.291809 & -0.217769 & -0.181911 & 0.704051 & 1.000000 & \\
\hline LBCI & -0.053823 & 0.046212 & 0.061525 & -0.421978 & -0.168661 & 1.000000 \\
\hline
\end{tabular}

Note: log of Covid-19 confirmed cases (LCOC), Log of COVID-19 Confirmed Death (LCOD), Log of Business Confidence Index (LBCI), Consumer Price Index (CPI), and Short-term Interest rate (INT).

Source: Authors' computation

Table 1 presents the descriptive statistics of the variables. The mean reveals that average FDI outflow and other variables are positive ranging from 3.6 to 9.75 over the period under consideration. The relative standard deviation shows that short-term interest rate has the highest variations, which is followed by Consumer price index. On the other hand, the least variation is recorded for Business confidence index. Table 2 shows the pairwise correlation between the variables. The correlation between log of COVID-19 confirmed cases and that of death is about 0.95 which is beyond the toleration rate. The same applies to CPI and INT. In order to avoid issue of multicollinearity, we do not include them in the same model in our estimations. 
Figure 2. The relationship between FDI outflows and COVID-19

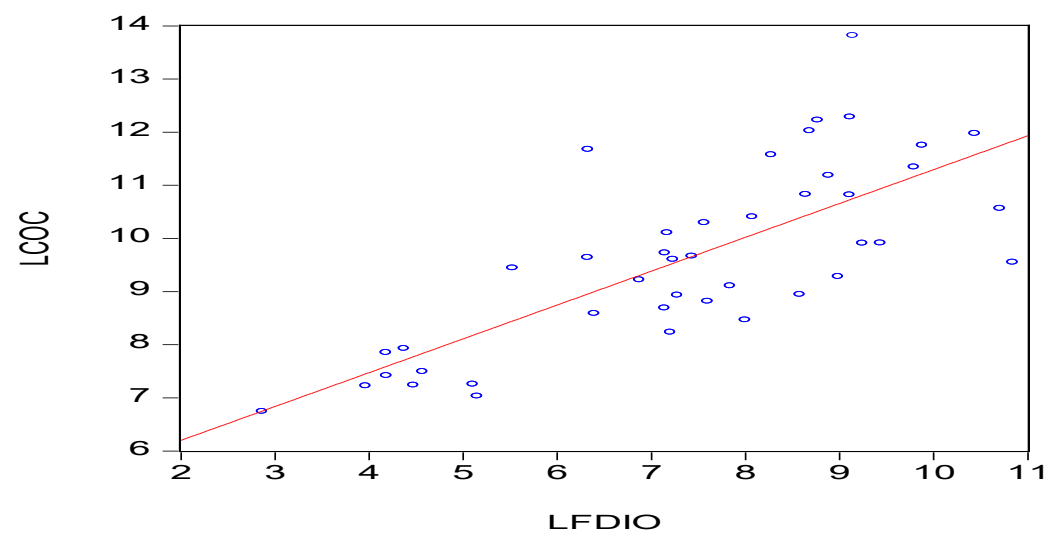

Source: Authors' computation

Figure 2 shows that there is a positive relationship between COVID-19 confirmed cases and FDI outflows. This means that COVID-19 increases the outflows of FDI in the economies. However, the main impact is established in the regression results in the next section.

\section{EMPIRICAL RESULTS}

\subsection{MAIN RESULTS}

Table 3 presents the results of the OLS regressions. The table shows that each independent variables are introduced especially the COVID-19 confirmed cases (LCOC) and COVID-19 confirmed Deaths (LCOD) to avoid problem of multicollinearity. The coefficients of LCOC and LCOD show positive and significant impact on FDI outflows. This means that COVID-19 increases the outflows of FDI in the studied countries. A one-percent increases in COVID-19 confirmed cases increase the outflows of foreign direct investment. In addition, column 4 shows that our measure of inflation (CPI) reduces the outflow of FDI in the economies. The F-Statistics in each column show the overall significance of the model. The P-value is less than one percent. Furthermore, the R-square shows that the explanatory power of the model is about $50-61 \%$. Overall, the results are in line with the submission of Stoddard and Noy (2015) who show that banking crisis and debt crisis has a negative impact on FDI inflows. This means that health or financial crisis increases FDI outflows in the economy. 
Table 3. OLS Results (Dependent Variable: LFDIO)

\begin{tabular}{|c|c|c|c|c|c|c|}
\hline & (1) & $(2)$ & (3) & (4) & $(5)$ & $(6)$ \\
\hline $\mathrm{LCOC}$ & $\begin{array}{l}0.895584 * * * \\
(0.0000)\end{array}$ & & $\begin{array}{l}0.872401 * * * \\
(0.0000)\end{array}$ & $\begin{array}{l}0.904527 * * * \\
(0.0000)\end{array}$ & & \\
\hline LCOD & & $\begin{array}{l}0.671533 * * * \\
(0.0000)\end{array}$ & & & $\begin{array}{l}0.684631 * * * \\
(0.0000)\end{array}$ & $\begin{array}{l}0.642790 * * * \\
(0.0000)\end{array}$ \\
\hline INT & & & $\begin{array}{l}-0.029341 \\
(0.3460)\end{array}$ & & & $\begin{array}{l}-0.017013 \\
(0.6030)\end{array}$ \\
\hline CPI & & & & $\begin{array}{l}-0.062532 * * \\
(0.0203)\end{array}$ & $\begin{array}{l}-0.043537 \\
(0.1132)\end{array}$ & \\
\hline LBCI & & & $\begin{array}{l}-4.027450 \\
(0.2663)\end{array}$ & $\begin{array}{l}-3.136268 \\
(0.3296)\end{array}$ & $\begin{array}{l}-2.544321 \\
(0.4495)\end{array}$ & $\begin{array}{l}-2.993674 \\
(0.4305)\end{array}$ \\
\hline Constant & $\begin{array}{l}-1.228371 \\
(0.3074)\end{array}$ & $\begin{array}{l}3.065616^{* * * *} \\
(0.0000)\end{array}$ & $\begin{array}{l}23.27953 \\
(0.2814)\end{array}$ & $\begin{array}{l}17.89603 \\
(0.3497)\end{array}$ & $\begin{array}{l}18.49526 \\
(0.3576)\end{array}$ & $\begin{array}{l}21.28509 \\
(0.3495)\end{array}$ \\
\hline R-sq. & 0.570413 & 0.537948 & 0.579279 & 0.601732 & 0.560436 & 0.531820 \\
\hline Adj. R-sq. & 0.559936 & 0.526678 & 0.538564 & 0.566591 & 0.521651 & 0.486512 \\
\hline F-statistic & $54.44058 * * *$ & $47.73457 * * *$ & $14.22769 * * *$ & $17.12321 * * *$ & $14.44980 * * *$ & $11.73794 * * *$ \\
\hline Prob(F-stat) & 0.000000 & 0.000000 & 0.000005 & 0.000001 & 0.000003 & 0.000027 \\
\hline No. of group & 43 & 43 & 43 & 43 & 43 & 43 \\
\hline
\end{tabular}

Source: Authors' computation

\subsection{ADDITIONAL RESULTS}

As aforementioned, we use Quantile regressions (QR) to further analyse the impact of COVID-19 pandemic on FDI outflows. Our QR estimation is based on the estimations in column 3 and 6 due to the potential multicollinearity that may occur between CPI variable and Interest rate (INT). Table 4 presents the QR results which show that there is a negative and significant impact of COVID-19 pandemic on FDI outflow at different levels of quantile. This means that the pandemic has really impacted the FDI severely in the economies.

Table 4. Quantile Regression Results (Dependent Variable: LFDIO)

\begin{tabular}{|c|c|c|c|c|c|c|}
\hline & Q.25 & Q.50 & Q.75 & Q.25 & Q.50 & Q.75 \\
\hline LCOC & & & & $\begin{array}{l}0.885647 * * * \\
(0.0000)\end{array}$ & $\begin{array}{l}0.926513 * * * \\
(0.0005)\end{array}$ & $\begin{array}{l}0.833625^{* * * *} \\
(0.0131)\end{array}$ \\
\hline LCOD & $\begin{array}{l}0.631495^{* * *} \\
(0.0000)\end{array}$ & $\begin{array}{l}0.469314^{* *} \\
(0.0277)\end{array}$ & $\begin{array}{l}0.503965^{* *} \\
(0.0226)\end{array}$ & & & \\
\hline INT & $\begin{array}{l}0.015942 \\
(0.7371)\end{array}$ & $\begin{array}{l}-0.028899 \\
(0.5328)\end{array}$ & $\begin{array}{l}-0.049149 \\
(0.1779)\end{array}$ & $\begin{array}{l}0.000302 \\
(0.9945)\end{array}$ & $\begin{array}{l}-0.012367 \\
(0.7675)\end{array}$ & $\begin{array}{l}-0.047917 \\
(0.1654)\end{array}$ \\
\hline LBCI & $\begin{array}{l}0.930673 \\
(0.9095)\end{array}$ & $\begin{array}{l}-4.588960 \\
(0.4010)\end{array}$ & $\begin{array}{l}-3.203282 \\
(0.3916)\end{array}$ & $\begin{array}{l}-1.665238 \\
(0.8207)\end{array}$ & $\begin{array}{l}-5.909658 \\
(0.2959)\end{array}$ & $\begin{array}{l}-3.419034 \\
(0.3332)\end{array}$ \\
\hline Constant & $\begin{array}{l}-3.232865 \\
(0.9477)\end{array}$ & $\begin{array}{l}32.33385 \\
(0.3178)\end{array}$ & $\begin{array}{l}24.39146 \\
(0.2697)\end{array}$ & $\begin{array}{l}7.984844 \\
(0.8562)\end{array}$ & $\begin{array}{l}33.94823 \\
(0.3103)\end{array}$ & $\begin{array}{l}20.82914 \\
(0.3190)\end{array}$ \\
\hline $\begin{array}{l}\text { Pseudo R-sq. } \\
\text { No. of group }\end{array}$ & $\begin{array}{l}0.420513 \\
43\end{array}$ & $\begin{array}{l}0.303727 \\
43\end{array}$ & $\begin{array}{l}0.269239 \\
43\end{array}$ & $\begin{array}{l}0.451147 \\
43\end{array}$ & $\begin{array}{l}0.335904 \\
43\end{array}$ & $\begin{array}{l}0.298641 \\
43\end{array}$ \\
\hline
\end{tabular}

Source: Authors' computation 


\section{CONCLUSION AND POLICY IMPLICATIONS}

Due to the impact of the ongoing worldwide COVID-19 crisis, FDI flows have been estimated to decline substantially. An extra decrease in FDI inflows could be expected in developed and developing countries, as the full consequences of the COVID-19 pandemic on transnational corporations' (TNCs) investment remained unfold. In this note, we examine the impact of COVID-19 pandemic on FDI outflows using cross-sectional first quarter, average data from 1 January - 31 March, 2020 of 43 countries. The evidence is based on Ordinary least square (OLS) and Quantile regressions. We document that there is a positive relationship between COVID-19 confirmed cases and FDI outflows. In addition, there is a positive impact of COVID-19 related confirmed deaths on FDI outflows across all quartiles estimations. This is confirmed at $99 \%$ confidence level that the COVID-19 health crisis affects the attractiveness of most economies which make multinational companies to relocate their investments during the first phases of COVID-19 pandemic.

In the light of the above, this note shows that COVID-19 pandemic fuels the foreign direct investment outflows in the economies due to a short supply of manpower caused by social distancing policy of governments, a reduction in financial resources of firms resulting from a decline in corporate profits and an increase in cost of finance in the financial market. In addition, the propensities to invest have been widely affected negatively in most economies. These factors also become obvious when most economies are currently experiencing a very high level of risk perception in financial market which has extensively curtailed the investment programmes of foreign investors in order to maintain a resilience in any further destructions in the home countries.

While these empirical results seem to be expected, this issue on COVID-19 pandemic and FDI flows is a necessary and timely one. The findings of this note are relevant not just because it shows the impact of the pandemic on FDI but because it provides insights on what most economies are likely to be experiencing during this new normal. Our results learn support from the aftermath of the 2008/2009 global financial crisis. Meanwhile, the possible long run impacts of this COVID-19 pandemic is yet to be seen, the current decline in economic activities are accompanied by a quick decrease in FDI flows globally. There is economic downturn everywhere and this note confirms a large increase in FDI outflow in the economies. In summary, this preliminary note supports the theoretical arguments on location advantages in attracting FDI. Another policy implications of this note is that there is need to improve public policies in wooing the confidence of foreign investors during economic challenges and government should ensure a conducive international business environment so as to attract a good number of FDI in any future crisis period.

One of the major limitations of this study relates to the use of 43 countries and the use of crosssectional data analysis. Future studies should shed more light on this issue using panel data analysis. 


\section{REFERENCES}

Alfaro, L., \& Chen, M. (2010). Surviving the global financial crisis: foreign direct investment and establishment performance, Harvard Business School Working Paper 10-110.

Andrés, A. R. (2006). Software piracy and income inequality. Applied Economic Letters, 13(2), 101105.

Aslam, M. A. (2015). A case study of cointegration relationship between tax revenue and foreign direct investment: Evidence from Sri Lanka. Second International Symposium - 2015, FIA, SEUSL

Asongu, S. A., Nwachukwu, J. C., Orim, S. M. I., \& Pyke, C. (2019). Crime and Social Media. Information Technology \& People, 32(5),1215-1233. https://doi.org/10.1108/ITP-06-20180280

Dornean, A., \& Oanea, D. C. (2015). Impact of the economic crisis on FDI in Central and Eastern Europe. Review of Economic \& Business Studies, 8(2), 53-68. DOI 10.1515/rebs-2016-0003

Dornean, A., Işan, V., \& Oanea, D. C. (2012). The impact of the recent global crisis on foreign direct investment. Evidence from Central and Eastern European Countries. Procedia Economics and Finance, 3(1),1012-1017.

Fairlie R. (2020). The impact of COVID-19 on small business owners: Evidence from the first 3 months after widespread social-distancing restrictions. J Econ Manage Strat, 1-14. https://doi. org/10.1111/jems.12400

Jelilov G., Iorember P.T., Usman O., \&Yua, P.M. (2020). Testing the nexus between stock market returns and inflation in Nigeria: Does the effect of COVID-19 pandemic matter? J Public Affairs. https://doi.org/10.1002/ pa.2289

InvestChile (2020). Impact of COVID-19 on the economy and FDI. InvestChile Investment Ebooks, Ahumada 11, Piso 12, Santiago, Chile. Available at www.investchile.gob.cl

Kian Wie, T. (2006). Policies for private sector development in Indonesia. ADB Institute Discussion Paper available at http://www.adbi.org/files/2006.03.d46.private.sector.dev.ind.pdf.

Kodila-Tedika, O., \& Asongu, S. A., (2015). The effect of intelligence on financial development: a cross-country comparison. Intelligence, 18, 1-9.

Koenker, R., \& Bassett, Jr. G. (1978). Regression quantiles. Econometrica, 46(1), 33-50.

Liu, X. (2012). The Impact of financial crises on foreign direct investment: evidence from developed countries. A Dissertation from the University of Nottingham, United Kingdom.

Organisation for Economic Co-operation and Development (2020). Foreign direct investment flows in the time of COVID-19. Tackling Coronavirus (COVID-19): Contributing to a global effort, oecd.org/coronavirus.

Poulsen, L., \& Hufbauer, G. (2011). Foreign Direct Investment in Times of Crisis. Peterson Institute of International Economics. Available at http://www.piie.com

Radu, C., Şova, R.-A., \& Popa, A. F. (2020). The impact of fdi over economic growth and how covid-19 crisis can impact the CEE economies. CECCAR Business Review, 4, 64-72. http://dx.doi. org/10.37945/cbr.2020.04.08

Seric, A., \& Hauge, J. (2020). COVID-19 and the global contraction in foreign direct investment. An online publication retrieved from https://oecd--development--matters-org.cdn. ampproject.org/v/s/oecd-development-matters.org/2020/06/29/covid-19-and-the-globalcontraction-in-foreign-direct-investment/amp/?usqp=mq331AQFKAGwASA\%3D\&amp

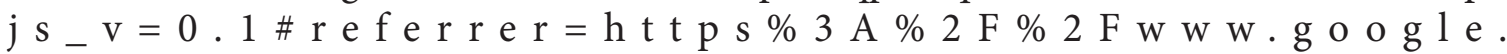
com \&aoh $=15989669203240 \& a m p \_c t=1598967105747 \& a m p \_t f=F r o m \% 20$ $\% 251 \% 24$ s \& a mpshare $=$ https \% 3 A \% 2 F \% 2 Foecd-development-matters. org\%2F $2020 \% 2 \mathrm{~F} 06 \% 2 \mathrm{~F} 29 \% 2 \mathrm{Fcovid}-19$-and-the-global-contraction-in-foreign-directinvestment $\% 2 \mathrm{~F}$ on 1 st September, 2020. 
Saurav, A., Kusek, P., \& Kuo, R. (2020). The impact of the coronavirus on foreign investors: Early evidence from a global pulse survey. An online publication retrieved from https://blogs. worldbank.org/psd/impact-coronavirus-foreign-investors-early-evidence-global-pulsesurvey on 1st September, 2020.

Stoddard, O., \& Noy, I. (2015). Fire-sale FDI? The impact of financial crises on foreign direct investment. Review of Development Economics, 19(2), 387-399,DOI:10.1111/rode.12149

Ucal, M., Özcan, K. M., Bilgin, M.H., \& Mungo, J. (2010). Relationship between financial crisis and foreign direct investment in developing countries using semiparametric regression approach, Journal of Business Economics and Management, 11(1): 2033.

UNCTAD. (2020). UNCTAD report details COVID-19 impacts on investment flows. An online publication retrieved from http://sdg.iisd.org/news/unctad-report-details-covid-19impacts-on-investment-flows/ on 1st September, 2020.

World Association of Investment Promotion Agencies (2020). The impact of COVID-19 from the perspective of IPAS. https://waipa.org/waipa-content/uploads/The-impact-of-COVID-19from-the-perspective-of-IPAs.pdf

Zhan, J. (2020). Covid-19 and investment - an UNCTAD research round-up of the international pandemic's effect on FDI flows and policy. Transnational Corporations, 27(1), 1-2. 